\title{
Endoscopic electrochemotherapy for esophageal cancer: a phase I clinical study
}

\section{다 (용}

\section{Authors}

Charlotte Egeland ${ }^{1}$, Lene Baeksgaard ${ }^{2}$, Helle Hjorth Johannesen ${ }^{3}$, Johan Löfgren ${ }^{3}$, Christina Caroline Plaschke ${ }^{4}$, Lars Bo Svendsen ${ }^{1}$, Julie Geh| ${ }^{5,6}$, Michael Patrick Achiam¹

\section{Institutions}

1 Department of Surgical Gastroenterology, Rigshospitalet, University of Copenhagen, Denmark

2 Department of Oncology, Rigshospitalet, University of Copenhagen, Denmark

3 Department of Clinical Physiology, Nuclear Medicine and PET, Rigshospitalet, University of Copenhagen, Denmark

4 Department of Otorhinolaryngology, Head and Neck Surgery \& Audiology, Rigshospitalet, University of Copenhagen, Denmark

5 Center for Experimental Drug and Gene Electrotransfer ( $C^{*}$ EDGE), Department of Clinical Oncology and Palliative Care, Herlev University Hospital, Copenhagen, Denmark

6 Department of Clinical Medicine, Faculty of Health and Medical Sciences, Zealand University Hospital, University of Copenhagen, Denmark

submitted 29.1.2018

accepted after revision 8.2 .2018

Bibliography

DOI https://doi.org/10.1055/a-0590-4053 |

Endoscopy International Open 2018; 06: E727-E734

(C) Georg Thieme Verlag KG Stuttgart · New York ISSN 2364-3722

Corresponding author

Charlotte Egeland, Department of Surgical

Gastroenterology, Rigshospitalet, University of

Copenhagen, Denmark, Blegdamsvej 9, DK-2100

Fax: +45342121

charlotte.egeland@gmail.com

\section{ABSTRACT}

Background and study aims Esophageal cancer is on the rise in the western world and the disease has a poor 5-year survival prognosis below $20 \%$. Electrochemotherapy is a treatment where a chemotherapeutic drug is combined with locally applied electrical pulses, in order to increase the drug's cytotoxicity in malignant cells. This study presents the first results with electrochemotherapy treatment in esophageal cancer.

Patients and methods In this first-in-human trial, six patients with advanced esophageal cancer were treated with electrochemotherapy using intravenous bleomycin. All side effects and adverse events (AEs) were registered and the patients were later evaluated with gastroscopy and 18F-fluorodeoxyglucose positron emission tomography/ magnetic resonance imaging (18F-FDG PET/MRI).

Results Treatment were well tolerated, main AEs being nausea, vomiting, oral thrush, pneumonia, retrosternal pain, fever, and hoarseness. No serious complications were observed. Five patients had a visual tumor response confirmed by gastroscopy. In two cases, these findings were confirmed with $18 \mathrm{~F}-\mathrm{FDG} \mathrm{PET} / \mathrm{MRI}$ as it revealed a reduction of total tumor mass.

Conclusion Electrochemotherapy in patients with advanced esophageal cancer was conducted without major safety concerns. This study paves the way for larger studies, which may further elucidate response rates for and side effects of this new treatment.

\section{Introduction}

Esophageal cancer is the eighth most commonly diagnosed cancer worldwide with approximately 456,000 patients per year [1]. In the western world, the incidence of esophageal cancer is rising and it is the sixth most common cause of cancerrelated death with a 5 -year survival of less than $20 \%$ [1]. In less than two-thirds of cases, patients are not eligible for surgery with curative intent. Thus, palliation is the main aim in management. Palliative treatment consists of chemotherapy, radiotherapy or combined chemoradiotherapy, as well as local surgical treatments such as dilatation and stenting, in addition to supportive care [2]. Different response rates and subsequent treatments with a high prevalence of reported side effects ( $\mathrm{fa}$ - 
tigue, vomiting, nausea, paresthesia, cardiac toxicity, kidney toxicity, and retrosternal pain) are, however, the common scenario [3]. Hence, new treatment options are warranted.

Electrochemotherapy combines electroporation with chemotherapy; reversible electroporation facilitates transport of molecules across the cell membrane. Short high-voltage pulses are applied to the malignant cells, which destabilize the membrane and create temporary pores [4]. Through these passages, large molecules (i.e. various types of cytostatic agents) that normally are impermeable to the cell membrane are able to cross into the cytosol [5]. Previous studies have proven bleomycin to be an efficient chemotherapeutic drug in combination with electroporation as it increases its cytotoxic ability more than 300 -fold [6,7]. The first clinical trial testing electrochemotherapy was reported in 1991 [8] and since then, several studies have investigated it in different cancer types [9-16]. To date, no human clinical studies regarding patients with esophageal cancer treated by electrochemotherapy have been reported.

The primary endpoint of this study was to evaluate the safety and feasibility of a novel endoscopic approach for electrochemotherapy in patients with an advanced esophageal cancer.

\section{Patients and methods}

\section{Study design}

This was a phase I, investigator-initiated, prospective, observational, non-comparative trial of electrochemotherapy in esophageal cancer. The primary endpoint was assessment of safety, and secondary endpoints were assessment of response measured by $18 \mathrm{~F}$-fluorodeoxyglucose positron emission tomography/magnetic resonance imaging (18F-FDG PET/MRI), gastroscopies, pain score (visual analog scale), dysphagia score (Mellow and Pink dysphagia score [17]), and quality of life questionnaires (European Organization for Research and Treatment of Cancer Quality of Life Questionnaire (EORTCQLQ-C30)).

\section{Patients}

The protocol allowed for inclusion of eight patients. Since the primary endpoint was safety in this phase I first-in-man trial, the subject number was low. Only patients ineligible for potentially curative intended surgery were candidates. Inclusion criteria were: age $\geq 18$ years, histologically verified malignant esophageal tumor (adenocarcinoma or squamous cell cancer), expected survival time $\geq 3$ months, WHO performance status $\leq 2$ [18], platelets $\geq 50$ billion/L, International Normalized Ratio $<1.5$ (medical correction was allowed), and s-creatinine $<150 \mu \mathrm{mol} / \mathrm{L}$. Moreover, patients had to have locally progressive disease despite previous treatment with chemoradiotherapy or locally progressive disease despite previous treatment with palliative radiotherapy and not be candidates for systemic chemotherapy. Written informed consent was required. Exclusion criteria were: non-correctable coagulation disorders, clinically significant cardiac arrhythmias, pregnancy or lactation/breastfeeding, concurrent treatment with another investigational medicinal product, contraindications for use of bleomycin (acute pulmonary infection, severe pulmonary disease, previously allergic reactions to bleomycin, or a previously regimen

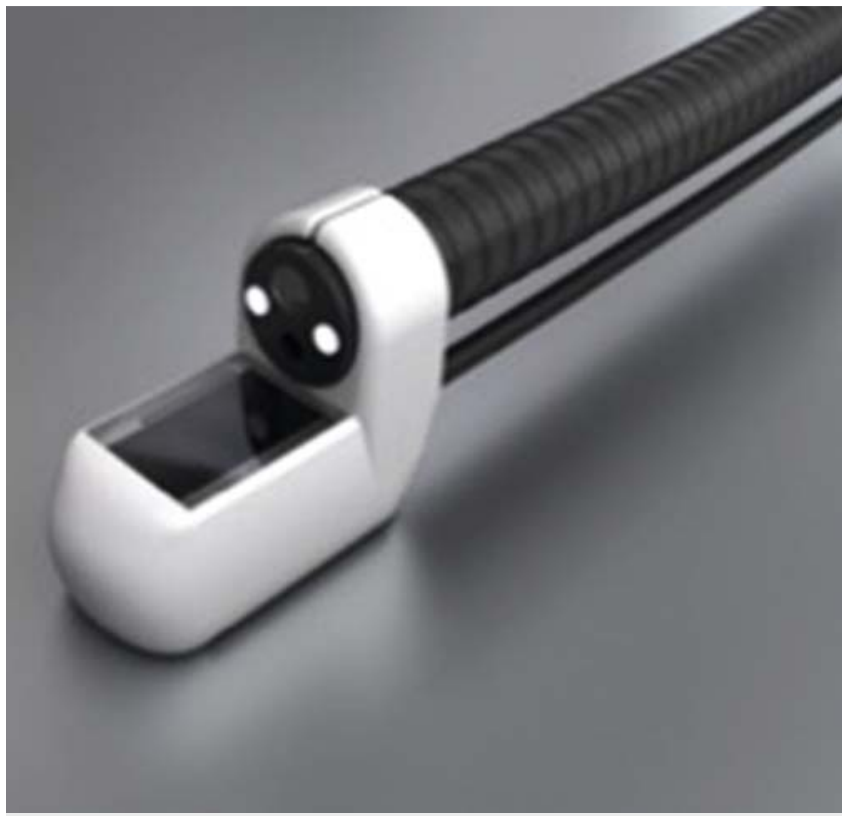

- Fig. 1 EndoVE (source: Cork Cancer Research Centre). Images of the device used in the trial- EndoVE ${ }^{\circledR}$. The electrode is attached to an endoscope. Tumor tissue is captured in place within the chamber $(1 \times 1 \times 1.5 \mathrm{~cm})$ of the device by a vacuum; this brings the tumor in contact with the two parallel electrodes which deliver pulses in $100 \mu$ s intervals. The procedure is repeated until the whole tumor area is covered.

of bleomycin with a cumulative dose $>240.000 \mathrm{UI} / \mathrm{m}^{2}$ ) or contraindications to 18F-FDG PET/MRI. Moreover, patients with any other clinical condition or prior therapy which, in the opinion of the investigator, would make them unsuitable for the study or unable to comply with the study requirements were not included. Women of childbearing potential and sexually active men had to use adequate contraception during the trial.

\section{Procedure}

Prior to the procedure, all patients had a full physical examination, blood biochemistry, a chest x-ray or chest computed tomography and an electrocardiogram. In addition, a baseline gastroscopy including biopsies and an 18F-FDG PET/MRI were done.

The treatment was performed under general anesthesia. Patients were anesthetized with propofol and remifentanil and endotracheal intubation was performed. To prevent cardiac arrhythmias, three electrodes were placed on the chest and connected to an AccuSync ECG triggering monitor (AccuSync 42 ECG triggering device, AccuSync Medical Research Corporation, Milford, Connecticut, United States). To minimize risk of lung toxicity from bleomycin, the fraction of inspired oxygen was limited to a maximum of $30 \%$ during anesthesia, according to ESOPE (European Standard Operating Procedure on Electrochemotherapy) [5]. Furthermore, patients were relaxed during the treatment to prevent muscle contractions. 
Bleomycin was administrated intravenously as 15,000 units/ $\mathrm{m}^{2}$ in a fast infusion diluted in $250 \mathrm{~mL}$ sodium chloride. Eight minutes after administration, the treatment began according to ESOPE [5]. The endoscopic electrode, EndoVE (Mirai Medical, Ireland) was attached to a scope ( $\triangleright$ Fig.1) and connected to a square wave pulse generator (Cliniporator, IGEA, Capri, Italy). The Cliniporator was further connected to a surgical suction pump $(0-760 \mathrm{mmHg})$ and the ECG triggering monitor. The Cliniporator delivered sequences consisting of eight pulses at $100 \mu$ s duration with a frequency of $5 \mathrm{kHz}$ and amplitude of $760 \mathrm{~V} / \mathrm{cm}$. After the electrode was placed on the tumor tissue, a vacuum was applied and the pulse sequences were delivered. This was repeated until the entire tumor area was covered. A nasal feeding tube was inserted and left in place for 7 days after treatment to ensure sufficient nutrition intake in case of local edema or post-treatment pain. Patients were discharged the same afternoon as the procedure or the day after.

\section{Image acquisition}

Baseline and follow-up 18F-FDG PET/MRI were performed on a 3 Tesla Biograph mMR (Siemens Medical Solutions). PET were acquired from mid-thoracic to upper gastrointestinal level acquired 60 minutes after administration of 18F-FDG with a dose of $4 \mathrm{MBq} / \mathrm{kg}$ preceded by at least 6 hours of fasting (one bed 6 minute acquisition using $3 \mathrm{D}$ OP-OSEM image reconstruction with 4 iterations, 21 subsets using a $344 \times 344$ matrix and a $4.0 \mathrm{~mm}$ Gaussian post-filter and Siemens standard four-compartment-attenuation map). Before the scanning, patients were given $20 \mathrm{mg}$ of hyoscinbutylbromid to reduce intestinal motility. The following MR sequences were acquired: T2weighted Half Fourier Acquisition Single Shot Turbo Spin Echo (HASTE) [TR $1500 \mathrm{~ms}$, TE $117 \mathrm{~ms}$, voxel size $1.5 \times 1.2 \mathrm{~mm}^{2}$, and 21 slices of $5.5 \mathrm{~mm}$ thickness] in sagittal, transversal and coronal orientation. Transversal HASTE and all following imaging were centered on the left part of the diaphragm. Imaging further comprised sagittal-oriented $\mathrm{T} 1$-weighted imaging [TR $4.25 \mathrm{~ms}$, TE $1.88 \mathrm{~ms}$, voxel size $1.7 \times 1.3 \mathrm{~mm}^{2}$, 52 slices of $4 \mathrm{~mm}$ thickness], transversal orientated HASTE [TR $1800 \mathrm{~ms}$, TE $95 \mathrm{~ms}$, voxel size $1.7 \times 1.2 \mathrm{~mm}^{2}$, and 35 slices of $5.0 \mathrm{~mm}$ thickness] and two echo planar Diffusion Weighted Imaging (DWI) [ $10300 \mathrm{~ms}$, TE $73 \mathrm{~ms}$, voxel size $3.7 \times 3.0 \mathrm{~mm}^{2}$, and 34 slices of $5.0 \mathrm{~mm}$ thickness] in transversal orientation with b-values of 0 , 50,400 , and $800 \mathrm{~s} / \mathrm{mm}^{2}$. T1 and T2 weighted imaging was performed in breath-hold, whereas DWI was respiratory triggered using a MR navigator placed on the diaphragm.

\section{Follow-up}

Seven days after treatment, all patients had a physical examination and patient-reported measures such as quality of life, dysphagia, and retrosternal pain score were recorded. This was repeated after 4 and 8 weeks. Safety was assessed by registering adverse events (AEs) and adverse device events (ADEs). An AE was defined as an event occurring during treatment or within 14 days after that was not present before. Severe adverse events (SAEs) were recorded according to Good Clinical Practice (GCP) provided by International Council for Harmonization of Technical Requirements for Pharmaceuticals for Human Use [19].

Response was evaluated via a gastroscopy and an 18F-FDG $\mathrm{PET} / \mathrm{MRI}$ at 4 and 8 weeks post-treatment. All gastroscopies were performed by a senior surgeon from the upper gastrointestinal team. The imaging response evaluation was performed by the same radiologists and nuclear physician working side by side. PET response was evaluated visually and by measuring maximum standardized uptake value (SUVmax) of the tumor and the treated region and $>30 \%$ decrease from baseline considered significant changes. MR anatomical imaging and diffusion-weighted imaging was assessed for visible tumor tissue, occurrence of metastatic disease, local lymph node involvement, treatment effects (edema of esophageal wall, formation of fibrous scar tissue) and treatment side effects. RECIST 1.1 criteria were not applied, as the treatment method is comparable to debulking surgery rather than systemic therapy.

Based on experience from the first patients, midway through the trial, supportive drugs were introduced to palliate side effects; prednisolone $50 \mathrm{mg}$ daily for 14 days followed by $25 \mathrm{mg}$ daily for 7 days, fluconazole $100 \mathrm{mg}$ daily for 2 weeks and ondansetron $8 \mathrm{mg}$ twice daily for 14 days.

\section{Ethics}

The intention of treatment was palliative and all included patients had already been offered palliative standard care without favorable response or were considered unsuitable for standard care. The protocol was approved by the Danish Medicines Agency, the Regional Ethics Committee ( $\mathrm{H}-16016381)$ and the Danish Data Protection Agency. EudraCT nr. 2015-005246-59. The trial was monitored by the Good Clinical Practice unit at Copenhagen University Hospital, Bispebjerg Hospital, Denmark.

\section{Statistics}

This was a small exploratory trial, so only descriptive statistics were used.

\section{Results}

\section{Patient characteristics}

Six men and one woman, aged 59 to 88 years, with a performance status $1-2$, and different comorbidities were included in the study ( $\vee$ Table 1 ). Six patients were treated whereas the first included patient could not participate due to a stent that could not be removed before the electrochemotherapy (ECT) procedure. The patients were treated between September 2016 and February 2017. Six patients had received oncological treatment for their esophageal cancer before enrollment. Four patients had loco-regional disease and three patients had metastatic disease. All seven patients used analgesics daily, and all but one could only take semifluid food or liquids when referred. 
- Table 1 Patients characteristics.

\begin{tabular}{|c|c|c|c|c|c|c|c|}
\hline $\begin{array}{l}\text { Patient } \\
\text { no. }\end{array}$ & $\begin{array}{l}\text { Sex } \\
\text { Age }\end{array}$ & $\begin{array}{l}\text { Primary } \\
\text { diagno- } \\
\text { sis }\end{array}$ & $\begin{array}{l}\text { TNM at diag- } \\
\text { nosis and } \\
\text { histology }\end{array}$ & Comorbidity & PS $^{1}$ & $\begin{array}{l}\text { Localization in } \\
\text { esophagus (from } \\
\text { incisor teeth) }\end{array}$ & $\begin{array}{l}\text { Previous oncological/ } \\
\text { surgical treatment }\end{array}$ \\
\hline 1 & $\begin{array}{l}\text { Male } \\
77 \mathrm{yr}\end{array}$ & $\begin{array}{l}\text { Jun } \\
2016\end{array}$ & $\begin{array}{l}\text { T3N1M0 } \\
\text { SCC }\end{array}$ & COPD & 2 & $32-40 \mathrm{~cm}$ & $\begin{array}{l}\text { Stent } \\
\text { RT: } 3 \text { Gy } \times 10 \mathrm{~F} \text { (esophagus) }\end{array}$ \\
\hline 2 & $\begin{array}{l}\text { Male } \\
59 \mathrm{yr}\end{array}$ & $\begin{array}{l}\text { May } \\
2015\end{array}$ & $\begin{array}{l}\text { T4bNOMO } \\
\text { ADC }\end{array}$ & $\begin{array}{l}\text { Liver insufficiency (Child } \\
\text { Pugh A), esophageal vari- } \\
\text { ces }\end{array}$ & 1 & $20-34 \mathrm{~cm}$ & $\begin{array}{l}\text { Capecitabine/oxaliplatin/ } \\
\text { trastuzumab } \\
\text { RCT: } 2 \text { Gy } \times 25 \mathrm{~F}+\text { Cisplatin/ } \\
5 \text { - fluorouracil } \\
\text { Docetaxel }\end{array}$ \\
\hline 3 & $\begin{array}{l}\text { Male } \\
60 \mathrm{yr}\end{array}$ & $\begin{array}{l}\text { Apr } \\
2015\end{array}$ & $\begin{array}{l}\text { T3N2M1 } \\
\text { ADC }\end{array}$ & $\begin{array}{l}\text { DMII } \\
\text { (Liver and osteolytic } \\
\text { metastases) }\end{array}$ & 2 & $\begin{array}{l}34-41 \mathrm{~cm} \\
\text { ("metastatic } \\
\text { islands" starting } \\
\text { from } 20 \mathrm{~cm} \text { ) }\end{array}$ & $\begin{array}{l}\text { Capecitabine/ trastuzumab } \\
\text { RT: } 3 \text { Gy } \times 10 \mathrm{~F} \text { (esophagus) } \\
\text { RT: } 5 \text { Gy } \times 5 \text { F (costae) }\end{array}$ \\
\hline 4 & $\begin{array}{l}\text { Male } \\
84 \mathrm{yr}\end{array}$ & $\begin{array}{l}\text { Feb } \\
2016\end{array}$ & $\begin{array}{l}\text { T2/3NOMO } \\
\text { ADC }\end{array}$ & $\begin{array}{l}\text { Hypertension, AF, epilepsy } \\
\text { Previous: prostate cancer }\end{array}$ & 2 & $34-42 \mathrm{~cm}$ & RT: 3 Gy $\times 10$ F (esophagus) \\
\hline 5 & $\begin{array}{l}\text { Male } \\
80 \mathrm{yr}\end{array}$ & $\begin{array}{l}\text { Apr } \\
2014\end{array}$ & $\begin{array}{l}\text { T1N1M0 } \\
\text { ADC }\end{array}$ & $\begin{array}{l}\text { Hypertension, AF, hy- } \\
\text { percholesterolemia, } \\
\text { essential thrombocytosis } \\
\text { Previous: ischemic stroke }\end{array}$ & 2 & $34-42 \mathrm{~cm}$ & RT: 3 Gy $\times 10$ F (esophagus) \\
\hline 6 & $\begin{array}{l}\text { Fe- } \\
\text { male } \\
72 \mathrm{yr}\end{array}$ & $\begin{array}{l}\text { Nov } \\
2015\end{array}$ & $\begin{array}{l}\text { TxNxM1 } \\
\text { ADC }\end{array}$ & $\begin{array}{l}\text { Hypertension, DMII } \\
\text { (Peritoneal carcinonoma- } \\
\text { tosis) }\end{array}$ & 1 & $38-40 \mathrm{~cm}$ & $\begin{array}{l}3 \text { Gy } \times 10 \mathrm{~F} \text { (esophagus) } \\
\text { Argon plasma coagulation } \\
\text { Capecitabine/oxaliplatin/ } \\
\text { trastuzumab } \\
\text { Irinotecan }\end{array}$ \\
\hline 7 & $\begin{array}{l}\text { Male } \\
88 \mathrm{yr}\end{array}$ & $\begin{array}{l}\text { Feb } \\
2017\end{array}$ & $\begin{array}{l}\text { T3NOMO } \\
\text { ADC }\end{array}$ & $\begin{array}{l}\text { Parkinson's disease, AA, } \\
\text { possible prostate cancer }\end{array}$ & 2 & $30-40 \mathrm{~cm}$ & None \\
\hline
\end{tabular}

COPD, chronic obstructive pulmonary disease; RT, radiotherapy; Gy, Gray; F, fraction; RCT, radiochemotherapy; SCC, squamous cell carcinoma; ADC, adenocarcinoma; DMII, diabetes mellitus type II; AF, atrial fibrillation; AA, aortic aneurysm

${ }^{1}$ Performance status according to WHO/ECOG [18]

- Table 2 Procedure.

\begin{tabular}{|c|c|c|c|c|c|}
\hline $\begin{array}{l}\text { Patient } \\
\text { no. }\end{array}$ & $\begin{array}{l}\text { Bleomycin } \\
\text { (IU) }\end{array}$ & $\begin{array}{l}\text { Pulse sequences of } \\
\text { each } 8 \text { pulses }(n)\end{array}$ & $\begin{array}{l}\text { Voltage applied } \\
\text { (V) }\end{array}$ & $\begin{array}{l}\text { Treatment duration } \\
\text { (min) }\end{array}$ & Comment \\
\hline 2 & 25,500 & 9 & 960 & 59 & $\begin{array}{l}\text { Due to stenosis only the oral } 5 \mathrm{~cm} \text { of the } \\
\text { tumor was treated. }\end{array}$ \\
\hline 3 & 28,350 & 32 & 960 & 37 & The entire tumor area was treated. \\
\hline 4 & 30,450 & 48 & 960 & 37 & The entire tumor was treated. \\
\hline 5 & 25,650 & 25 & 960 & 33 & $\begin{array}{l}\text { Due to stenosis, the caudal part of the } \\
\text { tumor was not treated. }\end{array}$ \\
\hline 6 & 29,100 & 16 & 960 & 31 & The entire tumor area was treated. \\
\hline 7 & 27,900 & 30 & 960 & 24 & $\begin{array}{l}\text { Due to stenosis, the caudal } 2 \mathrm{~cm} \text { of the } \\
\text { tumor was not treated. }\end{array}$ \\
\hline
\end{tabular}

\section{Treatment session}

Between nine and 48 electrical pulse sequences were delivered during the treatment sessions, depending on tumor size and cranial-caudal length. Treatment duration varied from 24 to 59 minutes ( $\triangleright$ Table 2 ). In three of the six treated patients, only the oral part of the tumor could be treated due to stricturing of the tumor that could not be passed by the electrode on the scope. 
- Table 3 Adverse events.

\begin{tabular}{|c|c|c|c|c|}
\hline Patient no. & Adverse events/reactions & CTCAE-grading & Serious adverse events/reactions & Survival \\
\hline \multirow[t]{7}{*}{2} & Fever/chills (<12 h) & 2 & \multirow{7}{*}{$\begin{array}{l}\text { Prolonged hospitalization within } 24 \text { h post- } \\
\text { treatment (fever). } \\
\text { Hospitalization after coughing up necrotic } \\
\text { tissue, no intervention. }\end{array}$} & \multirow[t]{7}{*}{3 months } \\
\hline & Hoarseness & 1 & & \\
\hline & Oral thrush & 1 & & \\
\hline & Pneumonia & 2 & & \\
\hline & Coughing up necrotic tissue & 1 & & \\
\hline & Dysphagia & 1 & & \\
\hline & Mucus & 1 & & \\
\hline \multirow[t]{7}{*}{3} & Fever/chills (<12 h) & 1 & \multirow{7}{*}{$\begin{array}{l}\text { Prolonged hospitalization within } 24 \text { h post- } \\
\text { treatment (fever). } \\
\text { Hospitalization due to nausea and dehydra- } \\
\text { tion. }\end{array}$} & \multirow[t]{7}{*}{2 months } \\
\hline & Hoarseness & 1 & & \\
\hline & Oral trush & 1 & & \\
\hline & Dehydration & 2 & & \\
\hline & Nausea/vomiting & 2 & & \\
\hline & Retrosternal pain & 2 & & \\
\hline & Weight loss & 1 & & \\
\hline \multirow[t]{2}{*}{4} & Retrosternal pain & 2 & \multirow{2}{*}{$\begin{array}{l}\text { Hospitalization due to food intake related } \\
\text { pain. }\end{array}$} & \multirow[t]{2}{*}{ Alive at 9 months } \\
\hline & Oral thrush & 1 & & \\
\hline \multirow[t]{2}{*}{5} & Dysphagia & 1 & \multirow[t]{2}{*}{ None } & \multirow[t]{2}{*}{ Alive at 7 months } \\
\hline & Weight loss & 1 & & \\
\hline \multirow[t]{4}{*}{6} & Nausea/vomiting & 1 & \multirow[t]{4}{*}{ None } & \multirow[t]{4}{*}{ Alive at 6 months } \\
\hline & Retrosternal pain & 1 & & \\
\hline & Weight loss & 1 & & \\
\hline & Oral thrush & 1 & & \\
\hline 7 & None & - & $\begin{array}{l}\text { Prolonged hospitalization }{ }^{1} \text { within } 48 \text { h post } \\
\text { treatment, due to problems placing feeding } \\
\text { tube. }\end{array}$ & 4 months \\
\hline $\begin{array}{l}\text { All adverse ev } \\
\text { CTCAE gradin } \\
{ }^{1} \text { Was not con }\end{array}$ & $\begin{array}{l}\text { icurring during the registration } \\
\text { aild, } 2=\text { moderate, } 3=\text { severe, } 4= \\
\text { as an actual serious adverse eve }\end{array}$ & $\begin{array}{l}14 \text { days post procedu } \\
\text { eatening, } 5=\text { death } r \\
\text { was not related to } t\end{array}$ & $\begin{array}{l}\text { reover, the serious adverse events are listed, as well } \\
\text { o } \mathrm{AE}[20] \text {. } \\
\text { o treatment but was still reported to the Danish Me }\end{array}$ & survival. \\
\hline
\end{tabular}

\section{Safety}

All AEs and ADEs occurring within 14 days post-treatment were recorded ( $\downarrow$ Table 3 ). No serious complications (perforation, perioperative bleeding or cardiac arrhythmias) related to the treatment session were recorded. No ADEs or device malfunctions concerning safety were reported. Among the first three patients, fever within 12 hours after treatment, hoarseness, coughing up necrotic tissue, oral thrush, pneumonia, dehydration, vomiting, nausea, retrosternal pain, and weight loss were reported. After supportive drugs (prednisolone, ondansetron and fluconazole) were introduced, incidence of AEs was reduced. Three patients had AEs leading to hospitalization after treatment. Duration of hospitalization length was from 1 to 3 days. Patient Number 2 died 3 months after the study treatment following a shorter hospitalization, most likely due to newly developed lung metastasis and pneumonia. The third pa- tient died 2 months after the given treatment, although he suffered from both liver and osteolytic metastasis on enrollment.

\section{Supportive treatment}

All though electrochemotherapy is well described for cutaneous tumors, this was the first study in esophageal cancer and special considerations may be necessary for this indication. Because the first treated patients in the study reported nausea, vomiting, oral thrush and problems swallowing, it was decided to prophylactically administer ondansetron ( $8 \mathrm{mg}$ twice daily for 14 days), prednisolone ( $50 \mathrm{mg}$ daily for 14 days followed by $25 \mathrm{mg}$ daily for 7 days), and prophylaxis for fungal infections (fluconazole $100 \mathrm{mg}$ daily for 14 days). The patients receiving this supportive treatment experienced fewer side effects ( $\vee$ Table 3$)$. 
Patient 2

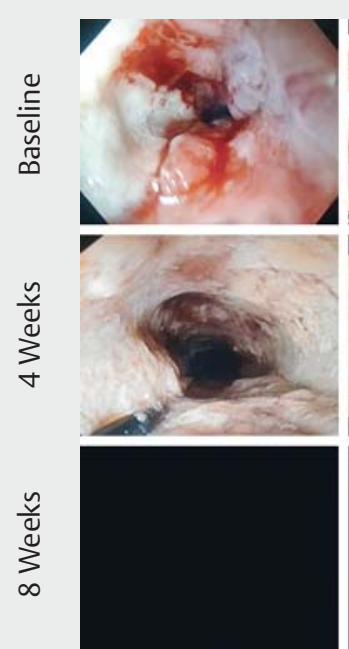

Patient 3
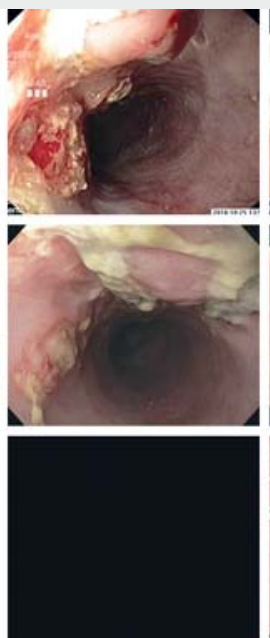

Patient 4
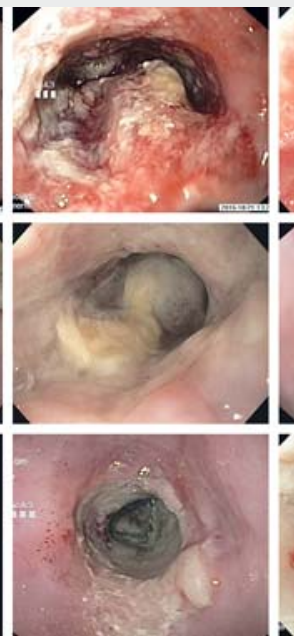

Patient 5
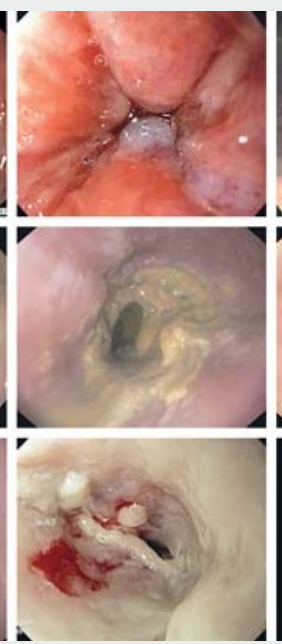

Patient 6
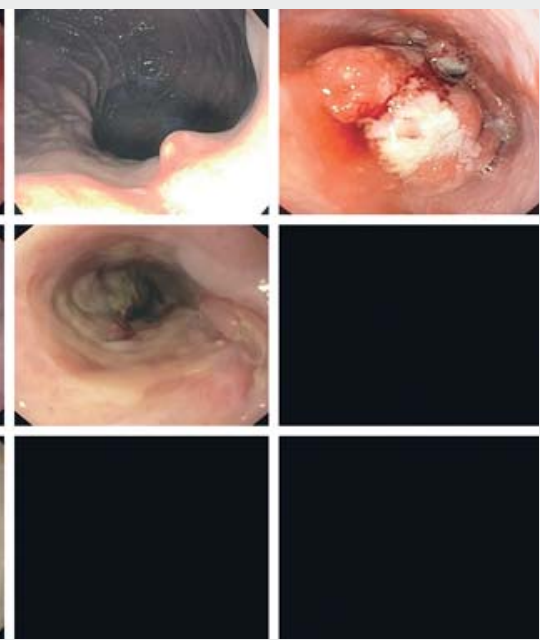

Patient 7

- Fig. 2 Endoscopic treatment response. Individual endoscopic treatment response. The image at the top shows the tumor before treatment, the images in the middle show the tumors after four weeks and the lowest line shows the tumor after eight weeks. Earlier ulcerated tissue is replaced with necrotic tissue with a fibrin layer and the tumors are found less exophytic. Not all patients had the 8 week endoscopy performed, where data are not available frames are left dark.
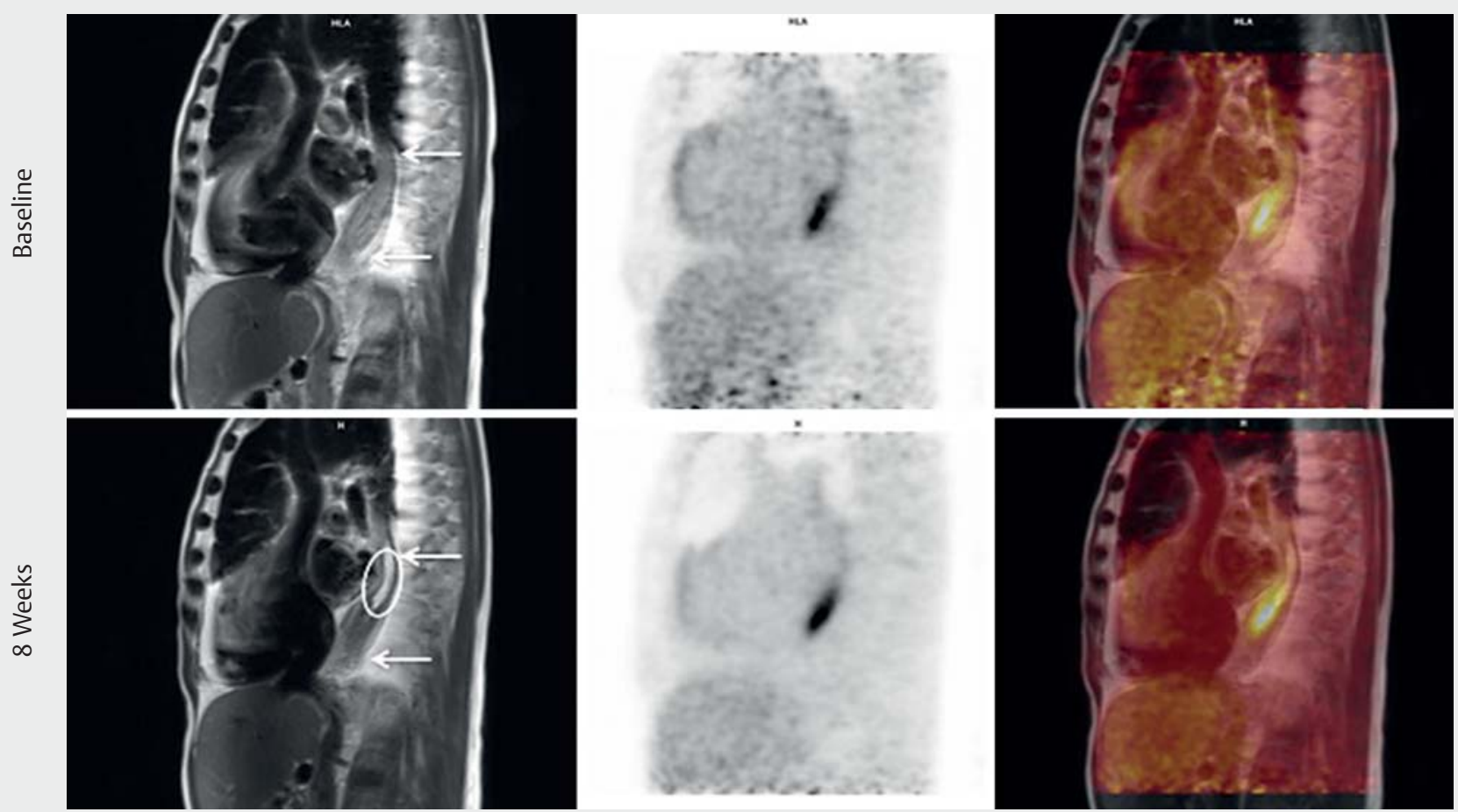

Fig. 3 Imaging treatment response. 18F-FDG PET/MRI from patient number 5. From left to right: MRI; 18F-FDG PET; 18F-FDG PET/MRI; MIP*-PET. The arrows show the tumor area; the circle shows the treated area at 8 weeks. Due to stenosis, the distal part could not be treated. In the treated area there is no sign of residual tumor and treatment sequelae is seen as fibrosis. There is no significant change in $18 \mathrm{~F}-\mathrm{FDC}$ activity (SUVmax at baseline 7,59, SUVmax at 8 weeks 7,06$).{ }^{*}$ Maximun intensity projection 
Table4 Description of response evaluation (18F-FDG PET/MRI).

\begin{tabular}{|c|c|}
\hline Patient no. & Imaging description \\
\hline 2 & $\begin{array}{l}4 \text { weeks: } \\
\text { No sign of residual tumor in the proximal part of } \\
\text { esophagus (treated area). Treatment sequelae in the } \\
\text { treated area, seen as fibrosis. No tumor progression } \\
\text { in non-treated area. } \\
\text { No significant changes in } 18 \text { F-FDG-activity. }\end{array}$ \\
\hline 3 & $\begin{array}{l}4 \text { weeks: } \\
\text { The amount of residual tumor could not be assessed. } \\
\text { No sign of local progression. Treatment sequelae, } \\
\text { seen as edema in the treated area. } \\
\text { No significant changes in } 18 \text { F-FDG-activity. }\end{array}$ \\
\hline 4 & $\begin{array}{l}8 \text { weeks: } \\
\text { No signs of local progression, amount of residual } \\
\text { tumor could not be assessed due to local edema } \\
\text { (treatment sequelae). } \\
\text { No significant changes in } 18 \text { F-FDG-activity. }\end{array}$ \\
\hline 5 & $\begin{array}{l}8 \text { weeks: } \\
\text { In the treated area there was no sign of residual } \\
\text { tumor. In the untreated, distal area there was no sign } \\
\text { of tumor progression. Treatment sequelae, seen as } \\
\text { fibrosis. } \\
\text { No significant changes in } 18 \text { F-FDG-activity. }\end{array}$ \\
\hline 6 & $\begin{array}{l}4 \text { weeks (evaluation from } \mathrm{CT}^{1} \text { ): } \\
\text { No visual changes in the treated area, no local pro- } \\
\text { gression. }\end{array}$ \\
\hline
\end{tabular}

Individual 18F-FDG PET/MRI response evaluation. Patient number 7 was lost to follow-up due to a head trauma.

${ }^{1}$ Declined the second PET/MRI.

\section{Follow-up and response evaluation}

Five of six treated patients were evaluated with gastroscopies and imaging (the last patient suffered head trauma unrelated to the treatment and could not be evaluated). Visual tumor response was reported from all postoperative gastroscopies. The esophageal mucosa demonstrating previous ulcerated tumor tissue was replaced with necrotic tissue covered with a fibrin layer ( Fig. 2). In two patients, these findings were confirmed by PET/MRI with a no longer visible residual tumor in the treated area ( $\triangleright$ Fig.3). One patient did not respond (evaluated with chest (T) and in two patients, the amount of residual tumor tissue could not be assessed on MR images. Tumor progression was not observed in any patient, but progression of regional, malignant suspicious lymph nodes was observed in one patient. Treatment sequelae were seen as fibrosis and/or local edema. Evaluation of PET images showed no significant change of 18FFDG-activity in the treated tumor areas on any follow-up images compared to baseline ( $\triangleright$ Table 4$)$.

\section{Adverse event report}

Three patients requested a second treatment, but due to a stricturing tumor in one case and poor performance status in the other two cases, a second treatment was considered unsuitable. On the EORTCQLQ-C30 assessment within the first 8 weeks after treatment, three patients reported impaired quali- ty of life, one patient reported an increase and one patient reported no change. The last patient was not assessed due to head trauma. The treatment did not have a pain relief effect in in any of the cases as evidenced by retrosternal pain score measured by Visual Analog Scale within the first 8 weeks posttreatment. Regarding dysphagia, four patients reported that it increased during the follow-up period (a maximum increment of one level at the used scale), one patient reported no change and one patient reported relief of dysphagia (decrement of one level of the used scale).

\section{Discussion}

In this first-in-human phase I study, endoscopic electrochemotherapy in patients with advanced esophageal cancer was technically feasible, without serious treatment-related complications. Moreover, tumor regression was observed.

No serious complications were reported, no AEs were rated higher than two based on CTCAE (Common Terminology Criteria for AEs) [20]. Most reported AEs were well-known side effects of electroporation and bleomycin, and they were further reduced after introduction of supportive drugs. The reported side effects should be considered in relation to the patients' stage of local disease, age and comorbidities. In further studies, this regimen may be further refined, but at this time, we would recommend it for the use of electroporation-based treatments in esophageal cancer. To evaluate efficiency and toxicity of bleomycin, a retrospective analysis of 57 patients with cutaneous tumors has suggested that a reduced dose of bleomycin ( 10000 or $13500 \mathrm{IU} / \mathrm{m}^{2}$ ) could be as efficient as the standard dose [21]. However, this must be prospectively confirmed before adoption in a clinical setting.

Tumor regression was visually confirmed endoscopically in all patients and was further confirmed with MRI in two patients. In this study, 18-F FDG activity does not seem suitable for evaluating treatment response this early in the follow-up period as there in all cases was unchanged increased activity in the treated region. Most likely this was due to a local inflammatory response, which was still active 8 weeks after treatment, possibly due to position of the tumor in the esophagus. The results from gastroscopies and MRI indicate that electrochemotherapy also induces tumor necrosis in that area. The study was not designed nor powered to show any relationship between gastroscopy or MRI finding and survival.

Several studies previously have investigated ECT in cutaneous tumors and cutaneous metastases where it is secondline therapy in many European countries. Mucosal tumors such as head-and-neck [12-14] and intestinal liver metastases [15] have also been evaluated with good response. Furthermore, electrochemotherapy has been illustrated in pancreatic cancer in a preclinical study [16]. Recently in a phase I study, electrochemotherapy was evaluated in colorectal cancer with an endoscopic electrode similar to the one used in this trial [22].

None of the patients reported pain relief, one patient reported an improvement in quality of life and two patients reported no change or a relief in dysphagia during the study period. The study design was not powered to demonstrate the palliative ef- 
fect of the treatment, as it was a safety and feasibly study. In addition, the majority of patients were diagnosed more than a year ago and were already suffering from both physical and psychological symptoms as well as existential considerations.

For less obstructive tumors the endoscopic electrode proved to be manageable, but for more obstructive tumors it was not possible to pass the stricture with the scope and the attached electrode. Consequently, impaired visibility could be a practical challenge. Further development of the electrodes as well as possibly treating the patients at stages before serious constriction could improve this situation.

\section{Conclusion}

In conclusion, this first-in-human study reports electrochemotherapy in patients with advanced esophageal cancer as feasible and safe, although stricturing tumors were challenging to treat. Tumor regression was reported in all patients from the gastroscopies and confirmed with MRI in two cases. Larger studies are warranted to further investigate electrochemotherapy for esophageal cancer, both with respect to response rate and more extensive reporting on quality-of-life data.

\section{Acknowledgement}

This work was supported by the Novo Nordisk Foundation [grant number NNF15OC0017882]. The electrodes were donated by Mirai Medical, Cork, Ireland and the work with the electrodes has been supported by Breakthrough Cancer Research and the Oesophageal Cancer Fund.

\section{Competing interests}

None

\section{References}

[1] World Health Organization. Globocan 2012: Estimated cancer incidence, mortality and prevalence worldwide in 2012. 2012: Available from: http://globocan.iarc.fr/Pages/fact_sheets_cancer.aspx [Accessed: 2017 May 01]

[2] Javle M, Ailawadhi S, Yang GY et al. Palliation of malignant dysphagia in esophageal cancer: a literature-based review. J Support Oncol 2006; 4: $365-73,379$

[3] American Cancer Society. Palliative therapy for cancer of the esophagus. Avaible from: https://www.cancer.org/cancer/esophagus-cancer/treating/palliative-therapy.html [Accessed: 2017 May 17]

[4] Sersa G, Miklavcic D, Cemazar M et al. Electrochemotherapy in treatment of tumours. Eur J Surg Oncol 2008; 34: 232 - 40

[5] Mir LM, Gehl J, Sersa G et al. Standard operating procedures of the electrochemotherapy: instructions for the use of bleomycin or cisplatin administered either systemically or locally and electric pulses delivered by the CliniporatorTM by means of invasive or non-invasive electrodes. Eur J Cancer 2006; 4: 14-25
[6] Gehl J, Skovsgaard T, Mir LM. Enhancement of cytotoxicity by electropermeabilization: an improved method for screening drugs. Anticancer Drugs 1998; 9: 319-325

[7] Tounekti O, Pron G, Belehradek JJr et al. Bleomycin, an apoptosis-mimetic drug that induces two types of cell death depending on the number of molecules internalized. Cancer Res 1993; 53: 5462 - 5469

[8] Belehradek M, Domenge C, Luboinski B et al. Electrochemotherapy, a new antitumor treatment. First clinical phase I-II trial. Cancer 1993; 72: $3694-3700$

[9] Gothelf A, Mir LM, Gehl J. Electrochemotherapy: results of cancer treatment using enhanced delivery of bleomycin by electroporation. Cancer Treat Rev 2003; 29: $371-387$

[10] Bertino G, Sersa G, De Terlizzi F et al. European research on electrochemotherapy in head and neck cancer (EURECA) project: results of the treatment of skin cancer. Eur J Cancer 2016; 63: 41-52

[11] Matthiessen LW, Johannesen HH, Hendel HW et al. Electrochemotherapy for large cutaneous recurrence of breast cancer: a phase II clinical trial. Acta Oncol 2012; 51: 713-721

[12] Landstrom FJ, Nilsson CO, Reizenstein JA et al. Electroporation therapy for T1 and T2 oral tongue cancer. Acta Otolaryngol 2011; 131: $660-664$

[13] Landstrom FJ, Reizenstein J, Adamsson GB et al. Long-term follow-up in patients treated with curative electrochemotherapy for cancer in the oral cavity and oropharynx. Acta Otolaryngol 2015; 135: 1070 1078

[14] Gargiulo M, Papa A, Capasso P et al. Electrochemotherapy for nonmelanoma head and neck cancers: clinical outcomes in 25 patients. Ann Surg 2012; 255: $1158-1164$

[15] Edhemovic I, Gadzijev EM, Brecelj E et al. Electrochemotherapy: a new technological approach in treatment of metastases in the liver. Technol Cancer Res Treat 2011; 10: 475-485

[16] Girelli R, Prejanò S, Cataldo I et al. Feasibility and safety of electrochemotherapy $(\mathrm{ECT})$ in the pancreas: a pre-clinical investigation. Radiol Oncol 2015; 49: 147-154

[17] Mellow MH, Pinkas H. Endoscopic therapy for esophageal carcinoma with Nd:YAG laser: prospective evaluation of efficacy, complications, and survival. Gastrointest Endosc 1984; 30: $334-339$

[18] Oken MM, Creech RH, Tormey DC et al. Toxicity and response criteria of the Eastern Cooperative Oncology Group. Am J Clin Oncol 1982; 5: $649-655$

[19] International Conference On Harmonisation Of Technical Requirements For Registration Of Pharmaceuticals For Human Use (ICH). ICH harmonised tripartite guideline: guideline for good clinical pratice 1996. 1996: Available from: https://www.ich.org/fileadmin/Public_Web_Site/ICH_Products/Guidelines/Efficacy/E6/E6_R1_Guideline. pdf [Accessed: 2017 Mar 10]

[20] Common terminology criteria for adverse events (CTCAE). Available from: https://www.eortc.be/services/doc/ctc/CTCAE_4.03_2010-0614_QuickReference_5x7.pdf [Accessed: 2018 Jan 01]

[21] Rotunno R, Campana LG, Quaglino P et al. Electrochemotherapy of unresectable cutaneous tumours with reduced dosages of intravenous bleomycin: analysis of 57 patients from the International Network for Sharing Practices of Electrochemotherapy registry. J Eur Acad Dermatol Venereol 2017: doi:10.1111/jdv.14708 [Epub ahead of print 2017 Nov 24]

[22] Falk HansenH, Stigaard T, Clover J et al. Electrochemotherapy for colo-rectal cancer using endoscopic electroporation; A phase I clinical study. Unpublished results. 